\title{
Ruminal degradability and intestinal digestibility of protein and amino acids in soybean and corn distillers grains products
}

\author{
K. Mjoun, K. F. Kalscheur, ${ }^{1}$ A. R. Hippen, and D. J. Schingoethe \\ Dairy Science Department, South Dakota State University, Brookings 57007
}

\section{ABSTRACT}

New fractionation and fermentation technologies in the ethanol industry have resulted in the production of different forms of distillers grains (DG). Such products are reduced-fat, high-protein, and "modified" wet feeds. Characterization of protein fractions of these co-products and other commonly used feedstuffs is important for the formulation of dairy cattle diets. In situ and in vitro techniques were conducted to compare crude protein (CP) availability in 4 DG products with commonly used soybean proteins. Soybean protein products included solvent-extracted soybean meal (SBM; $44 \%$ $\mathrm{CP})$, expeller soybean meal (ESBM), and extruded soybeans (ES). The DG products were conventional distillers dried grains with solubles, reduced-fat distillers dried grains with solubles (RFDGS), high-protein distillers dried grains, and modified wet distillers grains with solubles (MWDGS). Nylon bags containing $5 \mathrm{~g}$ of each feed were incubated in the rumen of 3 cannulated lactating cows for $2,4,8,16,24$, and $48 \mathrm{~h}$. The rapidly degradable CP fraction varied from 8.1 to $37.2 \%$ for SBM and MWDGS, respectively. The slowly degradable CP fraction was greatest for SBM, ES, and high-protein distillers dried grains $(88.0 \% \pm 3.7)$, followed by ESBM, distillers dried grains with solubles, and RFDGS (76.8 $\pm 4.1 \%)$. The MWDGS had the lowest slowly degradable CP fraction (61.1\%). The rate of degradation of the slowly degradable $\mathrm{CP}$ fraction ranged from 11.8 for SBM to $2.7 \%$ /h for RFDGS. Rumen-undegradable protein varied widely (32.3 to $60.4 \%$ ), with RFDGS having the greatest and SBM the lowest concentrations. Intestinal digestibility of rumen-undegradable protein (IDP) was estimated by pepsin-pancreatin digestion of ruminally preincubated $(16 \mathrm{~h})$ samples. The IDP was greatest for SBM, ESBM, and ES $(97.7 \% \pm 0.75)$, whereas IDP of DG products was $92.4 \% \pm 0.87$. Similarly, total digestible protein was greatest $(99.0 \%)$ for soybean products, whereas DG products had a total digestible protein of $96.0 \%$. Intestinal digestibility of most AA in DG products exceeded $92 \%$ and was slightly lower

Received November 5, 2009.

Accepted May 9, 2010.

${ }^{1}$ Corresponding author: kenneth.kalscheur@sdstate.edu than for soybean products, except for Lys, where the digestibility was $84.6 \%$ for DG compared with $97.3 \%$ for soybean products. Absorbable Lys was lower for DG $(7.0 \mathrm{~g} / \mathrm{kg}$ of CP) compared with ESBM and ES (average of $23.8 \mathrm{~g} / \mathrm{kg}$ of CP). Dried DG, ESBM, and ES provided more absorbable AA compared with SBM and MWDGS. These results suggest that the AA availability from DG products is comparable with that from soybean products.

Key words: distillers grains, rumen degradation, intestinal digestibility, amino acid

\section{INTRODUCTION}

Current models of nutrition express protein requirements in terms of MP, which is the sum of digestible protein from rumen microbes, RUP, and endogenous sources (Sniffen et al., 1992; NRC, 2001). In high-producing dairy cows, RUP represents a major contributor to metabolizable AA (NRC, 2001). Consequently, accurate estimation of the AA composition of the RUP fraction is important to formulate rations that will meet but not exceed the protein requirement of the animal. In terms of intestinal digestibility and AA profile, RUP varies widely among feedstuffs (Prestløkken and Rise, 2003). More specifically, the AA profile of the absorbed fraction of RUP can be markedly different from that of the original feed (Erasmus et al., 1994).

To improve transfer efficiency of dietary protein into milk protein, the ideal goal is to develop models that define the protein requirement in terms of AA rather than MP. However, the scarce data on intestinal digestibility of individual AA and the limited knowledge of their postabsorptive utilization limit such an approach. In addition, most protein systems (NRC, 2001; Rulquin et al., 2001) recognize that intestinal digestibility of RUP varies among feedstuffs; however, they assume that intestinal digestibility of individual AA that escape ruminal degradation is equal to the digestibility of RUP. Intestinal digestibility can vary widely depending on the feedstuff and specific AA (Hvelplund, 1985; O'Mara et al., 1997).

Distillers dried grains with solubles (DDGS) have a significant fraction of CP as RUP (Firkins et al., 
1984; Kleinschmit et al., 2007). The RUP digestibility of DDGS is assumed to be $80 \%$ (NRC, 2001), but there is indication in the literature that the actual value may be greater than $80 \%$. In fact, the intestinal digestibility of the RUP in DDGS has ranged from 84.0 to $91.0 \%$ (O'Mara et al., 1997; Kononoff et al., 2006; Janicek et al., 2008). These variations can lead to the underestimation of the amount of AA available for absorption.

Recent changes in ethanol production that maximize ethanol yield have resulted in the availability of a variety of distillers grains (DG) products of different chemical composition. One of these modified processes involves using a solvent extraction process that removes corn oil from DG, resulting in a product that is lower in fat compared with conventional DDGS. Other processes involve removing the germ or bran, or both, from corn before fermentation, resulting in a feed that is higher in $\mathrm{CP}$ concentration. This product does not contain solubles. Modified wet distillers grain with solubles (MWDGS) is essentially the same feed as the conventional DDGS except this feed goes through only 1 dryer and then solubles are added back to achieve a 50\% DM feed. With the availability of new products from the ethanol industry, characterization of the AA profile of RUP and their availability is important when including these coproducts in diets of dairy cows. Therefore, the objective of this study was to compare ruminal degradation and intestinal digestibility of $\mathrm{CP}$ and $\mathrm{AA}$ of different $\mathrm{DG}$ products with commonly fed soybean (SB) products, using in situ and in vitro techniques.

\section{MATERIALS AND METHODS}

\section{Feedstuffs}

Four products representing current trends observed in the ethanol industry were tested, including conventional DDGS, reduced-fat DDGS (RFDGS), high-protein distillers dried grains (HPDG), and MWDGS. All DG samples were supplied by VeraSun Energy (Brookings, SD) except for HPDG, which was manufactured by Poet (Sioux Falls, SD). The DDGS and MWDGS were from the same ethanol plant. The SB products included solvent-extracted SB meal (SBM; 44\% CP), expeller SB meal (ESBM), and extruded SB (ES).

The standard in situ procedure recommends using feed samples that have been ground through a $2-\mathrm{mm}$ screen (NRC, 2001). The particle size distribution of intact feedstuffs (data not shown; ASAE, 2004) showed differences in particle size distributions among feedstuffs; particles greater than $2.38 \mathrm{~mm}$ represented 24.6 and $1.7 \%$ of total particles for SB and DG products, respectively. Thus, SB products were ground to pass a 2-mm screen, whereas intact samples were used for DG products.

\section{Animals and In Situ Rumen Incubation}

The in situ procedure was conducted using 3 lactating dairy cows (247 DIM, $722 \mathrm{~kg}$ of BW, and $30 \mathrm{~kg} / \mathrm{d}$ of milk) fitted with rumen cannulas. Animals were fed for ad libitum consumption a typical lactation diet (CP $17.0 \%$, NDF $36.8 \%$, and ADF $25.3 \%$ of DM) based on corn silage and alfalfa with forage to concentration ratio of $45: 55 \%$. Daily DMI averaged $22.9 \pm 3.5 \mathrm{~kg} / \mathrm{d}$.

Samples (5 g; DM basis) of each feedstuff were weighed into nylon bags $(10 \times 20 \mathrm{~cm}, 53 \pm 10 \mu \mathrm{m}$ pore size; R1020, Ankom Technology, Macedon, NY) and heat sealed. Samples of each feedstuff were incubated, in duplicate, in the rumen of each cow for $0,2,4,8,16$, 24 , and $48 \mathrm{~h}$ (NRC, 2001). Before incubation, all bags were soaked in water $\left(39^{\circ} \mathrm{C}\right)$ for $15 \mathrm{~min}$ and then placed in a larger, weighted mesh bag $(36 \times 42 \mathrm{~cm})$ that was suspended below the particulate mat layer in the ventral sac of the rumen. Following rumen incubation, all Dacron bags were rinsed with cold water to remove particulate matter and then rinsed in a domestic washing machine on the delicate setting for approximately 5 min before draining. The cycle was repeated until effluent water remained clear. Intestinal digestibility of RUP (IDP) and AA were determined according to the modified 3-step procedure as described by Gargallo et al. (2006). Succinctly, 4 nylon bags containing $5 \mathrm{~g}$ (DM basis) of each feedstuff were incubated for $16 \mathrm{~h}$ in the rumen of the same 3 cannulated cows used for the in situ procedure. After ruminal incubation, bags were handled similarly as for ruminal degradation except that residues were lyophilized to avoid any potential protein damage that may occur with drying. Samples of $1 \mathrm{~g}$ of freeze-dried residues were weighed by triplicate into nylon bags $(5 \times 10 \mathrm{~cm}, 50 \mu \mathrm{m}$ pore size; Ankom R510, Ankom Technology) and heat sealed. Bags were sequentially incubated with constant rotation at $39^{\circ} \mathrm{C}$ with pepsin solution (P-7000, Sigma, St. Louis, MO) for $1 \mathrm{~h}$ and pancreatin solution (P-7545, Sigma) for 24 h using a Daisy incubator (Ankom Technology). A bottle containing 24 bags (3 bags per feedstuff) was used for each cow. Bags were rinsed with tap water after incubation until effluent water remained clear. Residues remaining after rumen incubation and pepsinpancreatin digestion were lyophilized to determine DM content, then pooled by feed for each cow and used for subsequent chemical analyses.

\section{Chemical Analysis}

All feed samples were ground to pass through a 2-mm screen of a Wiley mill (Arthur H. Thomas, Philadelphia, PA), then reground through a $1-\mathrm{mm}$ screen of an ultracentrifuge mill (Brinkman Instruments Co., 
Westbury, NY) and analyzed for DM $\left(105^{\circ} \mathrm{C}\right.$ for $\left.3 \mathrm{~h}\right)$. Concentrations of NDF (Van Soest et al., 1991) and ADF (Robertson and Van Soest, 1981) were determined sequentially using an Ankom fiber analyzer (Ankom Technology). Sodium sulfite and $\alpha$-amylase were added during NDF extraction.

Ether extract was determined using an Ankom ${ }^{\text {XT10 }}$ extractor (Ankom Technology) with petroleum ether as the solvent (method 920.39; AOAC, 2002). Ash, Ca, P, $\mathrm{K}, \mathrm{Mg}$, and $\mathrm{S}$ were analyzed according to AOAC (2002) procedures. Starch concentration was determined using an amylase assay kit (Megazyme International Ireland Ltd., Wicklow, Ireland; AOAC, 2002; method 996-11). Nitrogen concentration of original feeds, residues after ruminal incubation, and residues after pepsin-pancreatin digestion was determined according to AOAC (2002; method 968.06) using an automated N combustion analyzer (Rapid N cube, Elementar Analysensysteme GmbH, Hanau, Germany). Soluble protein, neutral detergent insoluble $\mathrm{CP}$, and acid detergent insoluble CP (ADICP) were determined on all feedstuffs according to the procedures described by Licitra et al. (1996). The AA concentrations of intact feeds and residues were determined by ultra performance liquid chromatography (Waters Acquity UPLC System, Milford, MA) with precolumn derivatization (AOAC, 2002; method 994.12, alternative I).

\section{Mathematical and Statistical Analysis}

In situ degradation curves of $\mathrm{CP}$ were fitted to a nonlinear model (Ørskov and McDonald, 1979) with or without lag phase. Because lag time was negligible for all feedstuffs, a model without lag time was retained as described by the following equation:

$$
\mathrm{Y}=\mathrm{A}+\mathrm{B}\left[1-\mathrm{e}^{-\mathrm{K}_{\mathrm{d}}(t)}\right]
$$

where $\mathrm{Y}=$ ruminal degradation of $\mathrm{CP}(\%)$; $\mathrm{A}=$ rapidly degradable $\mathrm{CP}$ that disappeared at $0 \mathrm{~h}$ after the rinsing procedure; $\mathrm{B}=$ potentially degradable $\mathrm{CP} ; \mathrm{K}_{\mathrm{d}}=$ constant rate of degradation of fraction $\mathrm{B}$; and $t=$ time of incubation (h). The undegradable fraction $\mathrm{C}$ was calculated as $100-(\mathrm{A}+\mathrm{B})$. Effective $\mathrm{CP}$ degradability representing RDP was determined by the equation

$$
\mathrm{RDP}=\mathrm{A}+\mathrm{B}\left[\mathrm{K}_{\mathrm{d}} /\left(\mathrm{K}_{\mathrm{d}}+\mathrm{Kp}\right)\right],
$$

where $\mathrm{A}, \mathrm{B}$, and $\mathrm{K}_{\mathrm{d}}$ are the degradation constants described previously (Ørskov and McDonald, 1979) and $\mathrm{Kp}$ is the passage rate from the rumen $(\% / \mathrm{h})$ calculated using the NRC (2001) equation for concentrates:

$$
\mathrm{Kp}=2.904+1.375 \times \mathrm{X} 1-0.020 \times \mathrm{X} 2,
$$

where $\mathrm{X} 1=\mathrm{DMI}$, percentage of $\mathrm{BW}$, and $\mathrm{X} 2=$ concentrate, percentage of diet DM. The passage rate was estimated to be $6.17 \% / \mathrm{h} \pm 0.54$. Estimated RUP of feeds was calculated as $100-\%$ RDP. Intestinally absorbable digestible protein (IADP) was determined as RUP $\times$ IDP. Total tract digestibility of CP was calculated as the sum of RDP and IADP. Contribution of RUP to intestinally absorbable AA (g/ $\mathrm{kg}$ of $\mathrm{CP}$ ) was calculated for each AA as (100 - \% rumen degradability at $16 \mathrm{~h}$ ) $\times \%$ intestinal disappearance in situ $\times$ AA concentration in the feed/10.

Degradation constants of CP described above were estimated using the NLIN procedure of SAS (SAS Institute, 2001). In situ degradation constants (A, B, C, $\mathrm{K}_{\mathrm{d}}$ ), RDP, RUP, IDP, IADP, total digestible protein (TDP), ruminal and in vitro intestinal digestibility of individual AA, and intestinally absorbable AA were analyzed using the MIXED procedure of SAS (SAS Institute, 2001) for each feed ingredient with cow as a random variable. The model for all variables was $\mathrm{Y}=$ feedstuff with cow as a random variable. Mean comparisons were performed using the Tukey test with $P<$ 0.05 designated as significant.

\section{RESULTS AND DISCUSSION}

\section{Feed Composition}

The chemical composition of tested ingredients is presented in Table 1. The CP concentration for SB products is comparable with published values (NRC, 2001). The NDF and ADF concentrations for SB products were slightly less than values reported in NRC (2001). Nutrient concentrations of DG products varied widely. Nutrient concentrations ranged from 29.7 to $41.5 \%$ for CP, 24.5 to $42.5 \%$ for NDF, and 3.2 to $12.8 \%$ for ether extract. These variations reflect differences in processing of DG products. Soluble protein as a percentage of $\mathrm{CP}$ was variable among feedstuffs, ranging from $6.4 \%$ for HPDG to $16.1 \%$ for MWDGS. The MWDGS had the greatest soluble protein among the DG products, possibly because of greater proportion of solubles added back to DG. The ADICP (\% of CP) varied from 1.8 to $13.2 \%$ for ES and RFDGS, respectively. Kleinschmit et al. (2007) reported ADICP values for different DDGS sources of 4.7 to $23.1 \%$. Increased ADICP values for DDGS may result from heat treatment during drying. Demjanec et al. (1995) observed similar increases in ADICP in heat-treated SBM. Although ADICP values of up to $10.7 \%$ for roasted SBM (Demjanec et al., 1995) and $10.3 \%$ for DDGS (Kleinschmit et al., 2007) have been shown to have no adverse effect on protein digest- 
Table 1. Chemical composition of soybean and distillers grains products

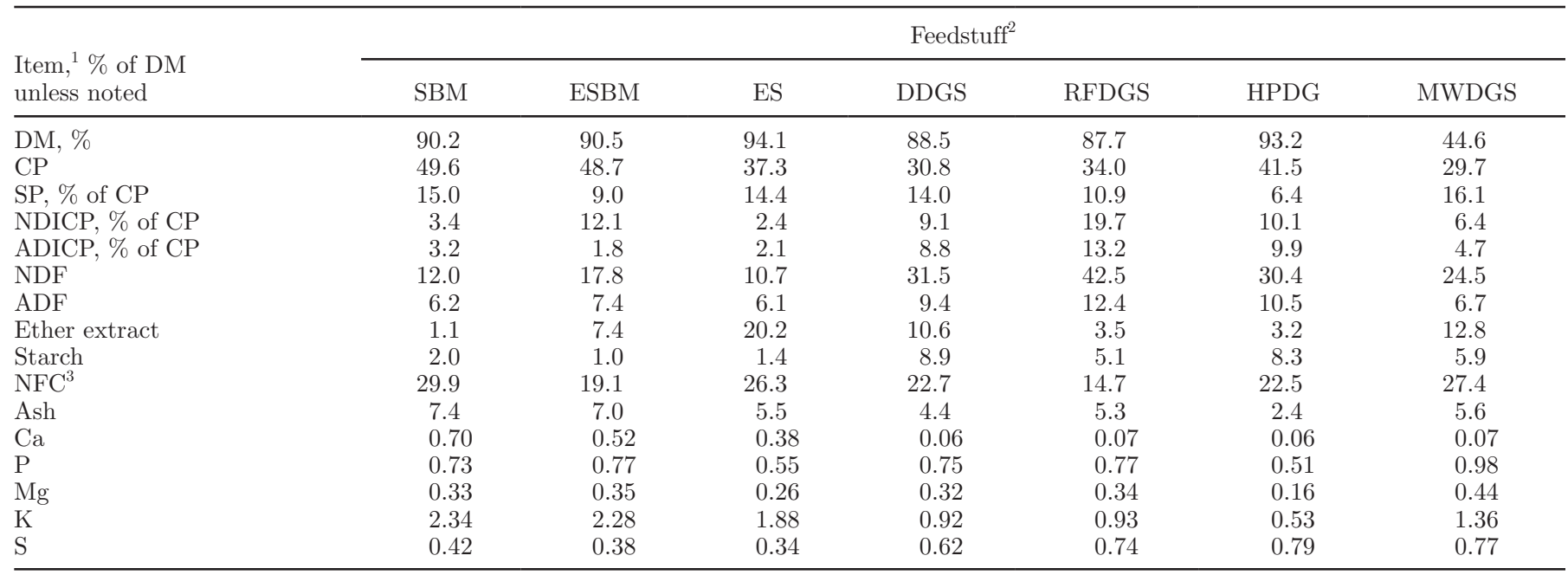

${ }^{1} \mathrm{SP}=$ soluble protein in borate buffer; NDICP = neutral detergent insoluble CP; ADICP = acid detergent insoluble CP.

${ }^{2} \mathrm{SBM}=$ soybean meal; ESBM = expeller soybean meal; ES = extruded soybeans; DDGS = distillers dried grains with solubles; RFDGS = reduced-fat distillers dried grains with solubles; HPDG = high-protein distillers dried grains; MWDGS = modified wet distillers grains with solubles.

${ }^{3} \mathrm{NFC}=100-(\% \mathrm{NDF}+\% \mathrm{CP}+\%$ ether extract $+\%$ ash $)$.

ibility, Kleinschmit et al. (2007) found that total protein digestibility of DDGS was decreased when ADICP was greater than $11.9 \%$ as a percentage of CP. In this experiment, RFDGS had an ADICP of $13.3 \%$, but only marginal decreases in intestinal and total digestible protein were observed, as will be discussed later.

The AA composition ( $\mathrm{g} / \mathrm{kg}$ of $\mathrm{CP}$ ) of feedstuffs is presented in Table 2. The AA profiles were different among feedstuffs. The AA composition of SB feedstuffs was within ranges found in NRC (2001). The AA composition of DG products was similar to concentrations reported by Pahm et al. (2009) for 7 different sources of DDGS. However, concentrations of most AA in DG products were greater than values reported in NRC (2001). In particular, mean Lys $(3.27 \% \pm 0.24)$ was greater than the $2.24 \%$ listed in NRC (2001), and Met $(1.99 \% \pm 0.06)$ compared with $1.82 \%$ in NRC (2001). Total essential AA (EAA; $42.4 \% \pm 1.4)$ was also greater than the $36.9 \%$ reported in NRC (2001). Lysine as percentage of EAA $(7.70 \% \pm 0.75)$ was greater than the $6.06 \%$ in NRC (2001). A higher concentration of AA in DG products may be an indication of improvement in the fermentation or drying processes in new-generation ethanol plants. In addition, feeding DG with greater concentrations of EAA may improve AA utilization by the mammary gland, especially of Lys as a potential limiting AA.

\section{Rumen Degradation Kinetics of CP and AA}

Differences in CP degradation parameters were observed among feedstuffs (Table 3 ). There was more rap- idly degradable CP (fraction A) in MWDGS (36.3\%) than in SBM (8.1\%). The range of fraction A (11.1 to $18.4 \%$ ) in dried DG samples (DDGS, RFDGS, and HPDG) agreed with values (15.9 to $19.7 \%$ ) reported by Kleinschmit et al. (2007). A range of 19.0 to $38.7 \%$ was reported for fraction A for wet DG (Kleinschmit et al., 2007; Cao et al., 2009). In addition, Cao et al. (2009) found a linear increase in fraction $\mathrm{A}$ when increased amounts of solubles were added to either dried or wet DG. The A fraction was greater for MWDGS compared with dried DG sources, indicating that differences in fraction A may be related to the amount of solubles added back to DG. Fraction A for SBM was less than the values (9.9 to 15\%) previously reported (NRC, 2001; Borucki Castro et al., 2007; Kleinschmit et al., 2007). Expeller SB had greater fraction A compared with an average reported value of $8.5 \%$ (NRC, 2001; Borucki Castro et al., 2007). Few estimates of CP degradability of ES are available for comparison (Nowak et al., 2005). Fraction A for ES in this experiment was within the range of 6.5 to $11.6 \%$ for SB extruded at temperatures of 165 and $145^{\circ} \mathrm{C}$, respectively (Nowak et al., 2005). The potentially degradable CP (fraction B) was greatest for SBM and least for MWDGS. The undegradable fraction $\mathrm{C}$ was not different among feedstuffs. Fraction $\mathrm{C}$ for SB products was similar to values reported previously (Nowak et al., 2005; Borucki Castro et al., 2007). The range of fraction $\mathrm{C}$ in $\mathrm{DG}$ products was within values reported by NRC (2001). The extent of fraction $\mathrm{C}$ may be related to heat damage of the protein. Kleinschmit et al. (2007) found that fraction C varied 
Table 2. Amino acid composition of soybean and distillers grains products

\begin{tabular}{|c|c|c|c|c|c|c|c|}
\hline $\begin{array}{l}\mathrm{AA}, \mathrm{g} / \mathrm{kg} \text { of } \mathrm{CP} \\
\text { unless noted }\end{array}$ & \multicolumn{7}{|c|}{ Feedstuff ${ }^{1}$} \\
\hline$\overline{\mathrm{Arg}}$ & 71.0 & 70.6 & 71.3 & 47.4 & 46.9 & 37.1 & 46.0 \\
\hline Ile & 48.0 & 50.2 & 48.1 & 40.4 & 43.1 & 41.8 & 38.7 \\
\hline Leu & 79.7 & 81.4 & 75.9 & 117.4 & 125.3 & 135.3 & 108.0 \\
\hline Lys & 64.7 & 60.5 & 67.0 & 34.8 & 32.2 & 29.5 & 34.3 \\
\hline Val & 50.0 & 48.0 & 50.0 & 53.0 & 53.4 & 51.4 & 51.5 \\
\hline Essential $\mathrm{AA}^{2}$ & 442.0 & 443.1 & 441.4 & 426.3 & 436.6 & 430.5 & 404.4 \\
\hline Ala & 43.3 & 43.1 & 42.6 & 69.3 & 71.2 & 73.1 & 67.5 \\
\hline Asp & 114.3 & 116.1 & 111.0 & 63.7 & 68.5 & 65.0 & 61.7 \\
\hline Cys & 14.7 & 13.8 & 15.4 & 19.3 & 18.1 & 18.3 & 17.9 \\
\hline Glu & 149.9 & 174.3 & 162.0 & 130.4 & 143.8 & 160.8 & 124.5 \\
\hline Lys, \% essential AA & 14.6 & 13.7 & 15.2 & 8.1 & 7.4 & 6.8 & 8.5 \\
\hline Met, $\%$ essential AA & 3.2 & 3.2 & 3.3 & 4.8 & 4.5 & 4.7 & 4.7 \\
\hline
\end{tabular}

${ }^{1} \mathrm{SBM}=$ soybean meal; ESBM = expeller soybean meal; ES = extruded soybeans; DDGS = distillers dried grains with solubles; RFDGS = reduced-fat distillers dried grains with solubles; HPDG = high-protein distillers dried grains; MWDGS = modified wet distillers grains with solubles.

${ }^{2}$ Sum of Arg, His, Ile, Leu, Lys, Met, Phe, Thr, and Val.

${ }^{3}$ Sum of Ala, Asp, Cys, Glu, Gly, Pro, and Ser.

${ }^{4}$ Total AA $=$ essential AA + nonessential AA.

widely from 2.1 and $18.7 \%$ for high-quality DDGS and a heat-damaged DDGS, respectively. The rate of degradation of fraction B $\left(\mathbf{K}_{\mathrm{d}}\right)$ was greatest $(11.8 \% / \mathrm{h})$ for SBM and least $(2.7 \% / \mathrm{h})$ for RFDGS. The $\mathrm{K}_{\mathrm{d}}$ was relatively greater for $\mathrm{SB}(8.0 \% / \mathrm{h} \pm 2.7)$ compared with DG products $(3.7 \% / \mathrm{h} \pm 0.7)$. The $\mathrm{K}_{\mathrm{d}}$ for $\mathrm{DG}$ products was within ranges reported (Kleinschmit et al., 2007; Cao et al., 2009).
Rumen-degradable protein varied from 39.6 to $67.7 \%$ depending on the feedstuff, with least and greatest values for SBM and RFDGS, respectively. Consequently, RUP was greatest for RFDGS (60.4\%) and least for SBM $(32.3 \%)$. The mean RUP for dried DG sources evaluated in this study was $55.7 \%$, with RFDGS having the greatest RUP. A wide range of RUP (47.8 to $87.2 \%$ ) for different DDGS sources is found in the literature

Table 3. Rumen degradation of CP for soybean and distillers grains products

\begin{tabular}{|c|c|c|c|c|c|c|c|c|}
\hline \multirow[b]{2}{*}{ Parameter $^{1}$} & \multicolumn{7}{|c|}{ Feedstuff $^{2}$} & \multirow[b]{2}{*}{ SEM } \\
\hline & SBM & ESBM & ES & DDGS & RFDGS & HPDG & MWDGS & \\
\hline $\mathrm{A}, \%$ & $8.1^{\mathrm{d}}$ & $11.4^{\mathrm{cd}}$ & $12.6^{\mathrm{c}}$ & $18.4^{\mathrm{b}}$ & $17.2^{\mathrm{b}}$ & $11.1^{\mathrm{cd}}$ & $37.2^{\mathrm{a}}$ & 0.91 \\
\hline B, $\%$ & $91.9^{\mathrm{a}}$ & $81.5^{\mathrm{ab}}$ & $87.4^{\mathrm{ab}}$ & $75.2^{\mathrm{bc}}$ & $73.7^{\mathrm{bc}}$ & $84.7^{\mathrm{ab}}$ & $61.1^{\mathrm{c}}$ & 3.80 \\
\hline C, $\%$ & 0.0 & 7.1 & 0.0 & 6.4 & 9.0 & 4.2 & 1.7 & 3.55 \\
\hline $\mathrm{K}_{\mathrm{d}}, \% / \mathrm{h}$ & $11.8^{\mathrm{a}}$ & $4.7^{\mathrm{b}}$ & $5.3^{\mathrm{b}}$ & $3.9^{\mathrm{b}}$ & $2.7^{\mathrm{b}}$ & $4.3^{\mathrm{b}}$ & $4.2^{\mathrm{b}}$ & 0.93 \\
\hline $\mathrm{RDP}, \%$ of $\mathrm{CP}$ & $67.7^{\mathrm{a}}$ & $46.3^{\mathrm{d}}$ & $52.0^{\mathrm{c}}$ & $47.7^{\mathrm{cd}}$ & $39.6^{\mathrm{e}}$ & $45.5^{\mathrm{d}}$ & $61.7^{\mathrm{b}}$ & 2.48 \\
\hline RUP, $\%$ of CP & $32.3^{\mathrm{e}}$ & $53.7^{\mathrm{b}}$ & $48.0^{\mathrm{c}}$ & $52.3^{\mathrm{bc}}$ & $60.4^{\mathrm{a}}$ & $54.5^{\mathrm{b}}$ & $38.3^{\mathrm{d}}$ & 2.48 \\
\hline
\end{tabular}

${ }^{\mathrm{a}-\mathrm{e}}$ Means within a row with different superscripts differ significantly $(P<0.05)$.

${ }^{1} \mathrm{~A}=$ rapidly degradable fraction of $\mathrm{CP} ; \mathrm{B}=$ potentially degradable fraction of $\mathrm{CP} ; \mathrm{C}=$ undegradable fraction of $\mathrm{CP} ; \mathrm{K}_{\mathrm{d}}=$ rate of degradation of fraction $\mathrm{B} ; \mathrm{RDP}=\mathrm{A}+\mathrm{B}\left[\mathrm{K}_{\mathrm{d}} /\left(\mathrm{K}_{\mathrm{d}}+\mathrm{Kp}\right) ; \mathrm{RUP}=\mathrm{B}\left[\mathrm{Kp} /\left(\mathrm{K}_{\mathrm{d}}+\mathrm{Kp}\right)\right]+\mathrm{C}\right.$, where $\mathrm{Kp}$ is the rate of passage from the rumen calculated to be $6.17 \% / \mathrm{h}$ (NRC, 2001).

${ }^{2} \mathrm{SBM}=$ soybean meal; ESBM = expeller soybean meal; ES = extruded soybeans; DDGS = distillers dried grains with solubles; RFDGS = reduced-fat distillers dried grains with solubles; HPDG = high-protein distillers dried grains; MWDGS = modified wet distillers grains with solubles. 
Table 4. Amino acid composition of soybean and distillers grains products residues after $16 \mathrm{~h}$ of ruminal incubation

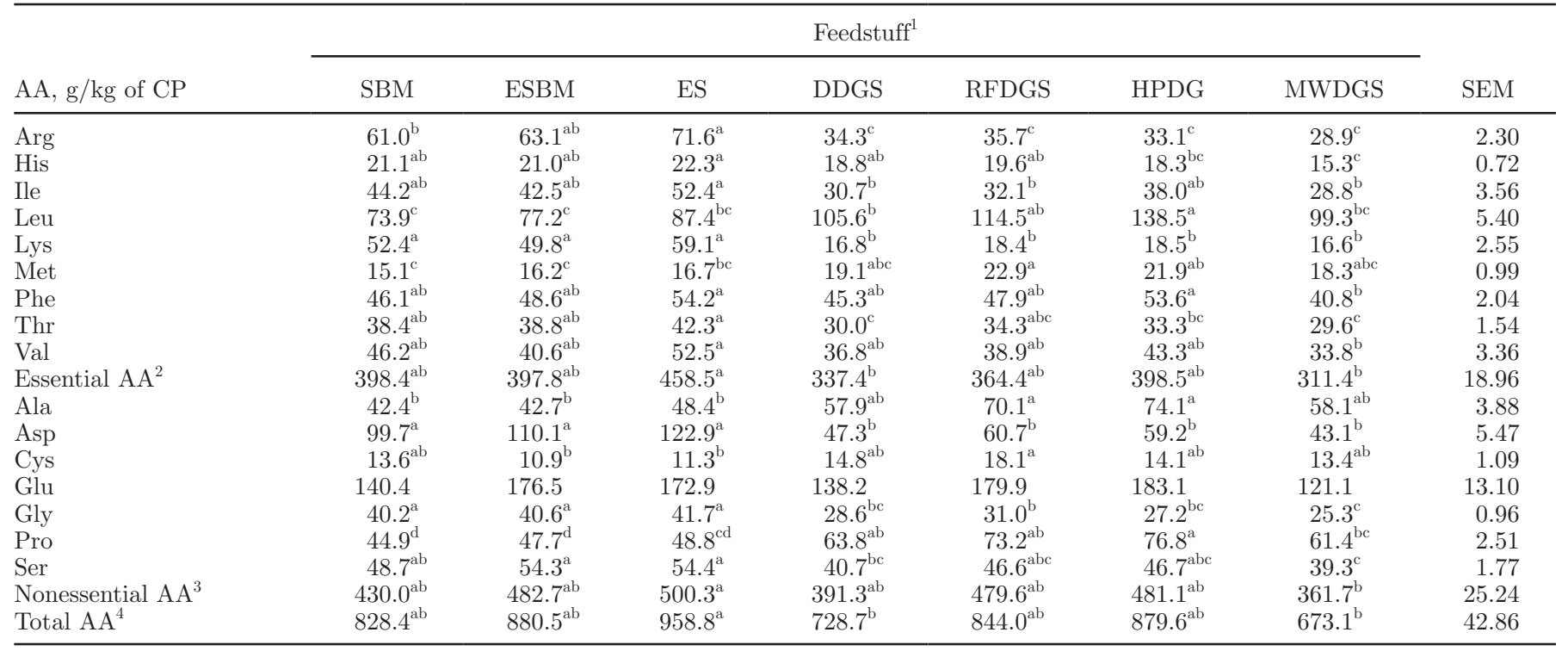

${ }^{\mathrm{a}-\mathrm{d}}$ Means within a row with different superscripts differ significantly $(P<0.05)$.

${ }^{1} \mathrm{SBM}=$ soybean meal; ESBM = expeller soybean meal; ES = extruded soybeans; DDGS = distillers dried grains with solubles; RFDGS = reduced-fat distillers dried grains with solubles; HPDG $=$ high-protein distillers dried grains; MWDGS = modified wet distillers grains with solubles.

${ }^{2}$ Sum of Arg, His, Ile, Leu, Lys, Met, Phe, Thr, and Val.

${ }^{3}$ Sum of Ala, Asp, Cys, Glu, Gly, Pro, and Ser.

${ }^{4}$ Total AA $=$ essential AA + nonessential AA.

(Firkins et al., 1984; Kleinschmit et al., 2007). NRC (2001) reported a value of $50.8 \%$ for cows consuming a diet containing $50 \%$ forage at $4 \% \mathrm{BW}$ intake. It is well known that heat treatment decreases protein availability (NRC, 2001); thus, variations in RUP concentrations are probably caused by differences in heat treatment during drying of DG. Estimated RUP in SBM was similar to the value reported in NRC (2001) but was less than an average value of $42.9 \% \pm 3.0$ (Maiga et al., 1996; Borucki Castro et al., 2007; Kleinschmit et al., 2007). The RUP for ESBM from this experiment was less than values reported (Maiga et al., 1996; NRC, 2001; Borucki Castro et al., 2007). Regarding ES, the RUP was similar to that obtained by Nowak et al. (2005). The RUP of treated SBM products (ESBM and ES) was higher than in SBM, which is consistent with previous reports (Prestløkken and Rise, 2003; Borucki Castro et al., 2007) where heat treatment of SB was shown to reduce protein degradation in the rumen.

The AA composition of the protein remaining after $16 \mathrm{~h}$ of ruminal incubation is presented in Table 4 . $\mathrm{Ru}-$ minal incubation consistently lowered concentrations of Arg, His, and Lys for all feedstuffs. Concentrations of most EAA, especially branched-chain AA (Leu, Ile, and Val), increased in the RUP fraction of ESBM after ruminal incubation compared with other feedstuffs. The comparison of $\mathrm{SB}$ with $\mathrm{DG}$ residues indicates that $\mathrm{SB}$ products had greater concentrations of Arg and Lys. Differences in individual EAA concentrations when comparing original feed and feed residues after ruminal incubation $(16 \mathrm{~h})$ are in agreement with Erasmus et al. (1994).

Rumen degradation of individual AA varied considerably among and within feedstuffs (Table 5). Among DG products, His and Lys were the most degraded, Ile, Thr, and Val were intermediate, and Leu, Met, and Phe were the least degraded in the rumen. Within SB products, Arg, His, and Lys were the most degraded among the EAA. In this experiment, Met was more resistant to rumen degradation in most feedstuffs compared with other EAA, an observation previously made by Tamminga (1979). Borucki Castro et al. (2007) found greater degradation of His and Lys than other EAA from SBM and other heated SBM products, including ESBM. However, these observations contrast with those of Maiga et al. (1996) and Prestløkken and Rise (2003), who reported slower degradation of Lys and His in ESBM than in SBM. Differences in the degradation rates of individual AA in the rumen may be related to differences in the type, physical properties, and AA composition of proteins (Clark et al., 1987; van Straalen et al., 1997). Overall, ruminal degradation of EAA and total AA degradation reflected the overall pattern of CP degradation. 
Table 5. Ruminal degradation (\%) of essential AA from soybean and distillers grains products after $16 \mathrm{~h}$ of ruminal incubation ${ }^{1}$

\begin{tabular}{|c|c|c|c|c|c|c|c|c|}
\hline $\mathrm{AA}$ & \multicolumn{7}{|c|}{ Feedsuff $^{2}$} & SEM \\
\hline$\overline{\mathrm{Arg}}$ & $85.1^{\mathrm{a}}$ & $59.4^{\mathrm{c}}$ & $56.0^{\mathrm{c}}$ & $65.6^{\mathrm{bc}}$ & $58.5^{\mathrm{c}}$ & $56.9^{\mathrm{c}}$ & $76.4^{\mathrm{ab}}$ & 3.09 \\
\hline Ile & $84.1^{\mathrm{a}}$ & $62.0^{\mathrm{b}}$ & $52.3^{\mathrm{b}}$ & $64.8^{\mathrm{ab}}$ & $59.4^{\mathrm{b}}$ & $56.1^{\mathrm{b}}$ & $72.0^{\mathrm{ab}}$ & 4.15 \\
\hline Leu & $83.9^{\mathrm{a}}$ & $57.2^{\mathrm{b}}$ & $49.6^{\mathrm{b}}$ & $58.5^{\mathrm{b}}$ & $50.1^{\mathrm{b}}$ & $50.5^{\mathrm{b}}$ & $65.5^{\mathrm{b}}$ & 3.52 \\
\hline Lys & $85.8^{\mathrm{a}}$ & $62.9^{\mathrm{cd}}$ & $61.3^{\mathrm{d}}$ & $76.8^{\mathrm{abc}}$ & $68.7^{\mathrm{bcd}}$ & $69.7^{\mathrm{bcd}}$ & $81.8^{\mathrm{ab}}$ & 3.04 \\
\hline Val & $83.4^{\mathrm{a}}$ & $63.7^{\mathrm{bc}}$ & $53.9^{\mathrm{c}}$ & $67.3^{\mathrm{abc}}$ & $60.2^{\mathrm{bc}}$ & $59.4^{\mathrm{bc}}$ & $75.3^{\mathrm{ab}}$ & 3.73 \\
\hline Essential $\mathrm{AA}^{3}$ & $84.4^{\mathrm{a}}$ & $59.5^{\mathrm{bc}}$ & $54.5^{\mathrm{c}}$ & $62.9^{\mathrm{bc}}$ & $54.4^{\mathrm{c}}$ & $55.3^{\mathrm{c}}$ & $71.1^{\mathrm{ab}}$ & 3.19 \\
\hline Total AA ${ }^{4}$ & $84.4^{\mathrm{a}}$ & $56.9^{\mathrm{bc}}$ & $53.7^{\mathrm{c}}$ & $61.1^{\mathrm{bc}}$ & $48.6^{\mathrm{c}}$ & $53.4^{\mathrm{c}}$ & $69.5^{\mathrm{ab}}$ & 3.46 \\
\hline
\end{tabular}

${ }^{\mathrm{a}-\mathrm{d}}$ Means within a row with different superscripts differ significantly $(P<0.05)$.

${ }^{1}$ Rumen disappearance (\%) at $16 \mathrm{~h}$ of incubation using in situ technique.

${ }^{2} \mathrm{SBM}=$ soybean meal; ESBM = expeller soybean meal; ES = extruded soybeans; DDGS = distillers dried grains with solubles; RFDGS = reduced-fat distillers dried grains with solubles; HPDG = high-protein distillers dried grains; MWDGS = modified wet distillers grains with solubles.

${ }^{3}$ Sum of Arg, His, Ile, Leu, Lys, Met, Phe, Thr, and Val.

${ }^{4}$ Total AA $=$ essential AA + nonessential AA (Ala, Asp, Cys, Glu, Gly, Pro, and Ser).

\section{Intestinal Digestibility of CP}

Intestinal digestibility of RUP was estimated following the procedure described by Gargallo et al. (2006) with the exception that determinations were made on 16-h rumen-preincubated samples. Calsamiglia and Stern (1995) found no difference in pepsin-pancreatin digestion of protein when samples were preincubated in the rumen for 12 to $18 \mathrm{~h}$. Intestinally digestible protein (Table 6) was greater for SB $(97.7 \% \pm 0.75)$ than DG products $(92.4 \% \pm 0.87)$. Intestinally digestible protein from DG products varied from $91.4 \%$ for RFDGS to 93.5\% for HPDG. These values are in agreement with results obtained using either the mobile bag technique (O'Mara et al., 1997; Kononoff et al., 2006; Janicek et al., 2008), the modified 3-step procedure (Boucher et al., $2009 \mathrm{~b}$ ), or the cecectomized rooster bioassay (Boucher et al., 2009a). In these reports, IDP in DDGS ranged from 84.0 to $92.8 \%$. The mean intestinal digestibility of $\mathrm{CP}$ for DG products in this experiment was $92.1 \%$ (97.0\% for SBM) in agreement with $91.8 \%$ (97.8\% for SBM) reported by Boucher et al. (2009b) using the same technique to estimate intestinal digestibility for 4 different DDGS products. The estimate for DDGS (Boucher et al., 2009b), however, was $76.7 \%$ (73.0\% for SBM) when determined using the original procedure of Calsamiglia and Stern (1995). Kleinschmit et al. (2007), using the original 3-step procedure, evaluated intestinal digestibility of different DDGS products and reported a wide range of intestinal digestibility, 59.2 to $76.8 \%$, with a mean of $68.2 \%$ ( $86.7 \%$ for SBM). The discrepancy between the original and the modified 3-step methods needs further investigation, although Gargallo et al. (2006) stated that the 2 methods resulted in similar estimates of intestinal CP digestion. The NRC (2001) model assumes an RUP digestibility of $80 \%$ for DDGS and $93 \%$ for SBM and ESBM. Results from this experiment and other aforementioned studies indicate that the actual IDP for DDGS may be greater than the value currently used by the NRC (2001) model.

\section{$T D P$}

There were small but significant differences in TDP among feedstuffs (Table 6). Total digestible protein varied from $94.8 \%$ for RFDGS to $99.2 \%$ for ESBM. Total digestible protein was greater for SB (99.1\%) compared with DG products (96.0\%). Total digestible protein from DG products estimated in this experiment was higher than values (70.7 to $85.3 \%$ ) reported by Kleinschmit et al. (2007). Estimated TDP for SB products in this experiment (99.0\%) was greater than the $93.9 \%$ reported for SBM in previous research (Kleinschmit et al., 2007). Lower estimated TDP values for DG in the later study may be attributed to 1) the method used to estimate intestinal digestibility as discussed previously and 2) difference in protein availability between DG samples from this experiment and those evaluated by Kleinschmit et al. (2007). Total tract disappearance of individual and total AA (data not presented) was greater for SBM, ESBM, and ES than for DG products. Overall, the extent of disappearance of individual EAA reflected that of $\mathrm{CP}$.

\section{Intestinal Digestibility of $A A$}

Intestinal digestibility of individual EAA are presented in Table 7 . There were small but significant 
Table 6. Protein digestibility of soybean and distillers grains products

\begin{tabular}{|c|c|c|c|c|c|c|c|c|}
\hline Parameter $^{1}$ & \multicolumn{7}{|c|}{ Feedstuff $^{2}$} & SEM \\
\hline IDP, $\%$ of RUP & $97.0^{\mathrm{a}}$ & $98.5^{\mathrm{a}}$ & $97.7^{\mathrm{a}}$ & $92.4^{\mathrm{b}}$ & $91.4^{\mathrm{b}}$ & $93.5^{\mathrm{b}}$ & $92.1^{\mathrm{b}}$ & 0.49 \\
\hline TDP, $\%$ of CP & $99.0^{\mathrm{a}}$ & $99.2^{\mathrm{a}}$ & $98.9^{\mathrm{a}}$ & $96.0^{\mathrm{bc}}$ & $94.8^{\mathrm{c}}$ & $96.5^{\mathrm{b}}$ & $97.0^{\mathrm{b}}$ & 0.25 \\
\hline
\end{tabular}

${ }^{\mathrm{a}-\mathrm{d}}$ Means within a row with different superscripts differ significantly $(P<0.05)$.

${ }^{1} \mathrm{IDP}=$ estimated intestinal protein digestibility $($ Gargallo et al., 2006); IADP $=$ intestinally absorbable dietary protein $=$ RUP $\times$ IDP; TDP $=$ total digestible dietary protein $=\mathrm{RDP}+\mathrm{IADP}$.

${ }^{2} \mathrm{SBM}=$ soybean meal; ESBM = expeller soybean meal; ES = extruded soybeans; DDGS = distillers dried grains with solubles; RFDGS = reduced-fat distillers dried grains with solubles; HPDG = high-protein distillers dried grains; MWDGS = modified wet distillers grains with solubles.

differences in digestibility of individual AA in the RUP fraction between SB and DG products except for Met, which was similar for all feedstuffs. In particular, Lys exhibited lower intestinal digestibility in DG (84.0\%) compared with SB $(97.3 \%)$ products. Lysine is the most heat-labile AA (Schwab, 1995). Boucher et al. (2009b) found that in vitro Lys digestibility was the most negatively affected by heat treatment of DDGS. In fact, Lys digestibility decreased from 86.0 to $32.4 \%$ following heat treatment of DDGS at $140^{\circ} \mathrm{C}$ for $1 \mathrm{~h}$. Intestinal digestibility of total EAA was greater in $\mathrm{SB}$ $(98.2 \%)$ than in DG products (93.3\%) partly because of the lower intestinal digestibility of Lys. Individual AA digestibility coefficients for SBM, ESBM, and dried DG products in this experiment were similar to estimates using either the precision-fed cecectomized rooster bioassay or the modified 3-step procedure (Boucher et al., 2009a,b). Individual and total AA digestibility for ES was higher than those obtained with the precision-fed cecectomized rooster assay (Aldrich et al., 1997). Most protein systems assign a constant digestibility coefficient for AA that escapes ruminal degradation (NRC, 2001; Rulquin et al., 2001). However, as demonstrated in this study and previously (Hvelplund, 1985; O'Mara et al., 1997; Boucher et al., 2009b), the range of intestinal digestibility can widely vary depending on the individual AA and the feedstuff. Differences of intestinal digestibility among EAA in different DG products suggest that individual AA digestibility, at least for Lys, should be applied in feed formulation systems.

\section{$I A D P$ and $A A$}

Because of high RUP combined with high IDP in dried DG products, the IADP supplied from dried DG exceeded that from SB products (Table 6). The IADP varied from 31.3 to $55.2 \%$ of CP for SBM and RFDGS, respectively. Dried DG products provided the largest IADP, with a mean of $51.5 \%$ of CP. Kleinschmit et al.
(2007) reported a much wider range of IADP, varying from 41.1 to $59.0 \%$. Results from this study may indicate that less protein damage occurred during processing and, consequently, more protein may be available for absorption in the small intestine. Furthermore, considering that all 3 sources of dried DG were supplied from different ethanol plants, it can be concluded that current DDGS processing methods may be more attentive to the susceptibility of heat damage.

The estimated intestinally absorbable amount of each EAA ( $\mathrm{g} / \mathrm{kg}$ of $\mathrm{CP}$ ) supplied by the RUP fraction is presented in Table 8. Absorbable Lys was greatest for ESBM and ES. Absorbable Lys averaged $7.0 \mathrm{~g} / \mathrm{kg}$ of CP for all dried DG products. Soybean meal supplied less absorbable Met compared with dried DG products. Dried DG products provided similar absorbable EAA as ESBM and ES products. The MWDGS supplied less absorbable EAA compared with other DG because of greater ruminal degradation. Kleinschmit et al. (2007) estimated metabolizable AA from different DDGS incubated in the rumen for $12 \mathrm{~h}$ and reported similar values of absorbable Lys and Met, averaging 8.6 and $8.0 \mathrm{~g} / \mathrm{kg}$ of $\mathrm{CP}$, respectively. Difference in absorbable AA among feedstuffs resulted mainly from differences in rumen degradability and to a lesser extent to intestinal digestion. Estimates of intestinally absorbable AA for SBM and ESBM were lower than those reported previously (Borucki Castro et al., 2007; Kleinschmit et al., 2007). The main factor contributing to differences in AA availability between this study and those previously cited was the difference in rumen degradability. For example, estimated available Lys averaged $22.3 \mathrm{~g} /$ $\mathrm{kg}$ of CP for SBM (Borucki Castro et al., 2007; Kleinschmit et al., 2007) compared with $8.9 \mathrm{~g} / \mathrm{kg}$ of $\mathrm{CP}$ in this experiment. In addition, ruminal degradation of Lys of 53.6 to $61.9 \%$ (Borucki Castro et al., 2007; Kleinschmit et al., 2007) was significantly lower than the value of $85.8 \%$ found in this experiment. Because SBM and MWDGS were more degraded in the rumen than 
Table 7. Intestinal digestibility (\%) of essential AA from RUP of soybean and distillers grains products ${ }^{1}$

\begin{tabular}{|c|c|c|c|c|c|c|c|c|}
\hline $\mathrm{AA}$ & \multicolumn{7}{|c|}{ Feedstuff $^{2}$} & SEM \\
\hline$\overline{\operatorname{Arg}}$ & $98.5^{\mathrm{a}}$ & $99.4^{\mathrm{a}}$ & $98.9^{\mathrm{a}}$ & $92.7^{\mathrm{b}}$ & $93.0^{\mathrm{b}}$ & $93.4^{\mathrm{b}}$ & $91.8^{\mathrm{b}}$ & 0.63 \\
\hline Ile & $97.7^{\mathrm{a}}$ & $98.9^{\mathrm{a}}$ & $98.6^{\mathrm{a}}$ & $93.3^{\mathrm{b}}$ & $93.3^{\mathrm{b}}$ & $93.3^{\mathrm{b}}$ & $93.6^{\mathrm{b}}$ & 0.82 \\
\hline Leu & $97.7^{\mathrm{ab}}$ & $99.1^{\mathrm{a}}$ & $98.6^{\mathrm{a}}$ & $96.0^{\mathrm{b}}$ & $95.7^{\mathrm{b}}$ & $95.5^{\mathrm{b}}$ & $95.9^{\mathrm{b}}$ & 0.58 \\
\hline Lys & $96.1^{\mathrm{a}}$ & $98.7^{\mathrm{a}}$ & $97.1^{\mathrm{a}}$ & $83.9^{\mathrm{b}}$ & $85.8^{\mathrm{b}}$ & $86.9^{\mathrm{b}}$ & $81.7^{\mathrm{b}}$ & 1.57 \\
\hline Thr & $97.5^{\mathrm{a}}$ & $99.0^{\mathrm{a}}$ & $98.6^{\mathrm{a}}$ & $87.9^{\mathrm{bc}}$ & $89.5^{\mathrm{bc}}$ & $91.0^{\mathrm{b}}$ & $86.8^{\mathrm{c}}$ & 0.78 \\
\hline Val & $97.1^{\mathrm{a}}$ & $98.6^{\mathrm{a}}$ & $98.4^{\mathrm{a}}$ & $92.0^{\mathrm{b}}$ & $91.9^{\mathrm{b}}$ & $92.4^{\mathrm{b}}$ & $91.6^{\mathrm{b}}$ & 0.90 \\
\hline Essential $\mathrm{AA}^{3}$ & $97.3^{\mathrm{a}}$ & $98.9^{\mathrm{a}}$ & $98.4^{\mathrm{a}}$ & $93.3^{\mathrm{b}}$ & $93.4^{\mathrm{b}}$ & $93.8^{\mathrm{b}}$ & $92.7^{\mathrm{b}}$ & 0.69 \\
\hline Total $\mathrm{AA}^{4}$ & $97.0^{\mathrm{ab}}$ & $98.9^{\mathrm{a}}$ & $98.3^{\mathrm{a}}$ & $93.4^{\mathrm{c}}$ & $93.9^{\mathrm{bc}}$ & $94.0^{\mathrm{bc}}$ & $92.8^{\mathrm{c}}$ & 0.75 \\
\hline
\end{tabular}

${ }^{\mathrm{a}-\mathrm{c}}$ Means within a row with different superscripts differ significantly $(P<0.05)$.

${ }^{1}$ Intestinal disappearance (\%) of 16 -h rumen residues using in vitro technique.

${ }^{2} \mathrm{SBM}=$ soybean meal; ESBM = expeller soybean meal; ES = extruded soybeans; DDGS = distillers dried grains with solubles; RFDGS = reduced-fat distillers dried grains with solubles; HPDG = high-protein distillers dried grains; MWDGS = modified wet distillers grains with solubles.

${ }^{3}$ Sum of Arg, His, Ile, Leu, Lys, Met, Phe, Thr, and Val.

${ }^{4}$ Total AA $=$ essential AA + nonessential AA (Ala, Asp, Cys, Glu, Gly, Pro, and Ser).

other feedstuffs, contributions of RUP to intestinally absorbable protein and AA were marginal. The ratio of absorbable Lys to Met was greater for SB $(3.43 \pm 0.24)$ compared with DG products $(0.78 \pm 0.04)$. NRC (2001) suggested that maximal milk protein production will be achieved when diets are formulated at concentrations of 7.2 and $2.4 \%$ as a percentage of MP for Lys and Met, respectively. These concentrations correspond to a Lys to Met ratio of 3. Based on the recommendations of
NRC (2001), feeding SB products is expected to result in maximal milk protein synthesis, whereas feeding DG products as the sole source of supplemental protein may result in decreased milk protein synthesis. These results (Table 8) also demonstrate that AA concentration contained in IADP is markedly different from that of the original feed. For this reason, accurately estimating AA presented to the duodenum is a challenging task that needs to be achieved.

Table 8. Estimated intestinally absorbable AA supplied by the RUP of soybean and distillers grains products ${ }^{1}$

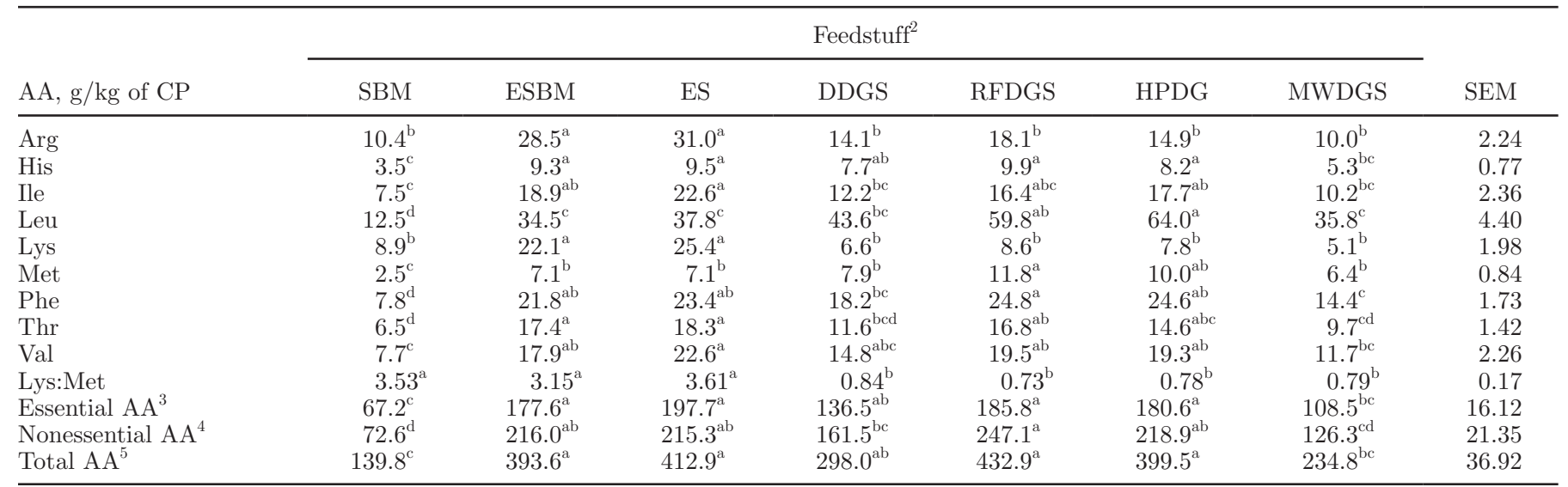

\footnotetext{
${ }^{\mathrm{a}-\mathrm{d}}$ Means within a row with different superscripts differ significantly $(P<0.05)$.

${ }^{1}$ Absorbable AA supplied by RUP is defined as $(100-\%$ rumen degradability at $16 \mathrm{~h}) \times(\%$ intestinal disappearance in situ $) \times$ AA concentrations in the feed/10.

${ }^{2} \mathrm{SBM}=$ soybean meal; ESBM = expeller soybean meal; ES = extruded soybeans; DDGS = distillers dried grains with solubles; RFDGS = reduced-fat distillers dried grains with solubles; HPDG = high-protein distillers dried grains; MWDGS = modified wet distillers grains with solubles.

${ }^{3}$ Sum of Arg, His, Ile, Leu, Lys, Met, Phe, Thr, and Val.

${ }^{4}$ Sum of Ala, Asp, Cys, Glu, Gly, Pro, and Ser.

${ }^{5}$ Total $\mathrm{AA}=$ essential AA + nonessential AA.
} 


\section{CONCLUSIONS}

Ruminal degradation of CP was greater in SBM and MWDGS than in other feedstuffs evaluated (ESBM, ES, DDGS, RFDGS, and HPDG). Dried DG products in particular were more resistant to ruminal degradation compared with SB products and MWDGS. As a result, more protein escaped the rumen as RUP in dried DG sources. Dried DG sources are an excellent source of IADP. Ruminal and intestinal disappearance coefficients were dependent on individual AA and feedstuffs. However, intestinal digestibility of AA was slightly different (exceeded $92.0 \%$ for all EAA) among feedstuffs; these differences are eventually of minimal practical importance except that of Lys, which was relatively less in DG $(84.6 \%)$ compared with SB products $(97.3 \%)$. The high intestinal digestibility of the RUP fraction for the dried DG products compensated for the low ruminal degradation, resulting in similar quantities of absorbable EAA as ESBM and ES. Distillers dried grains are a highly digestible source of RUP but a poorer source of absorbable Lys, a factor that needs to be taken into account when feeding DG to dairy cows.

\section{ACKNOWLEDGMENTS}

The authors thank Alvaro Garcia (South Dakota State University, Brookings) for his valuable comments during the preparation of the manuscript. This work was supported in part by the South Dakota Agricultural Experiment Station (Brookings) and USDA-ARS Agreement No. 58-5447-7-322. This project was also supported by USDA-CSREES National Research Initiative Competitive Grant No. 2007-35206-17901.

\section{REFERENCES}

Aldrich, C. G., N. R. Merchen, C. M. Parsons, H. S. Hussein, S. Ingram, and J. R. Clodfelter. 1997. Assessment of postruminal amino acid digestibility of roasted and extruded whole soybeans with the precision-fed rooster assay. J. Anim. Sci. 75:3046-3051.

AOAC. 2002. Official Methods of Analysis. 17th ed. Assoc. Off. Anal. Chem., Gaithersburg, MD.

ASAE. 2004. ASAE Standards 2004. Am. Soc. Agric. Eng., St. Joseph, MI.

Borucki Castro, S. I., L. E. Phillip, H. Lapierre, P. W. Jardon, and R. Berthiaume. 2007. Ruminal degradability and intestinal digestibility of protein and amino acids in treated soybean meal products. J. Dairy Sci. 90:810-822.

Boucher, S. E., S. Calsamiglia, C. M. Parsons, H. H. Stein, M. D. Stern, P. S. Erickson, P. L. Utterback, and C. G. Schwab. 2009a. Intestinal digestibility of amino acids in rumen-undegraded protein estimated using a precision-fed cecectomized rooster bioassay: II. Distillers dried grains with solubles and fish meal. J. Dairy Sci. 92:6056-6067.

Boucher, S. E., S. Calsamiglia, C. M. Parsons, M. D. Stern, M. Ruiz Moreno, M. Vázquez-Añón, and C. G. Schwab. 2009b. In vitro digestibility of individual amino acids in rumen-undegraded protein: The modified three-step procedure and the immobilized digestive enzyme assay. J. Dairy Sci. 92:3939-3950.
Calsamiglia, S., and M. D. Stern. 1995. A three-step in vitro procedure for estimating intestinal digestion of protein in ruminants. J. Anim. Sci. 73:1459-1465.

Cao, Z. J., J. L. Anderson, and K. F. Kalscheur. 2009. Ruminal degradation and intestinal digestibility of dried or wet distillers grains with increasing concentrations of condensed distillers solubles. J. Anim. Sci. 87:3013-3019.

Clark, J. H., M. R. Murphy, and B. A. Crooker. 1987. Supplying the protein needs of dairy cattle from by-product feeds. J. Dairy Sci. 70:1092-1109.

Demjanec, B., N. R. Merchen, J. D. Cremin Jr., C. G. Aldrich, and L. L. Berger. 1995. Effect of roasting on site and extent of digestion of soybean meal by sheep: I. Digestion and nitrogen and amino acids. J. Anim. Sci. 73:824-834.

Erasmus, L. J., P. M. Botha, and C. W. Cruywagen. 1994. Amino acid profile and intestinal digestibility in dairy cows of rumenundegradable protein from various feedstuffs. J. Dairy Sci. $77: 541-551$.

Firkins, J. L., L. L. Berger, G. C. Fahey Jr., and N. R. Merchen. 1984. Ruminal nitrogen degradability and escape of wet and dry distillers grains and wet and dry corn gluten feeds. J. Dairy Sci. 67:1936-1944.

Gargallo, S., S. Calsamiglia, and A. Ferret. 2006. Technical note: A modified three-step in vitro procedure to determine intestinal digestion of proteins. J. Anim. Sci. 84:2163-2167.

Hvelplund, T. 1985. Digestibility of rumen microbial protein and undegraded dietary protein estimated in the small intestine of sheep and by in sacco procedure. Acta Agric. Scand. Suppl. 25:132-144.

Janicek, B. N., P. J. Kononoff, A. M. Gehman, and P. H. Doane. 2008. The effect of feeding dried distillers grains plus solubles on milk production and excretion of urinary purine derivatives. J. Dairy Sci. 91:3544-3553.

Kleinschmit, D. H., J. L. Anderson, D. J. Schingoethe, K. F. Kalscheur, and A. R. Hippen. 2007. Ruminal and intestinal digestibility of distillers grains plus solubles varies with source. J. Dairy Sci. 90:2909-2918.

Kononoff, P. J., S. K. Ivan, and T. J. Klopfenstein. 2006. Estimation of the proportion of feed protein digested in the small intestine of cattle consuming wet corn gluten feed. J. Dairy Sci. 89:3968 3971.

Licitra, G., T. M. Hernandez, and P. J. Van Soest. 1996. Standardization of procedures for nitrogen fractionation of ruminant feeds. Anim. Feed Sci. Technol. 57:347-358.

Maiga, H. A., D. J. Schingoethe, and J. E. Henson. 1996. Ruminal degradation, amino acid composition, and intestinal digestibility of the residual components of five protein supplements. J. Dairy Sci. 79:1647-1653.

Nowak, W., S. Michalak, and S. Wylegala. 2005. In situ evaluation of ruminal degradability and intestinal digestibility of extruded soybeans. Czech J. Anim. Sci. 50:281-287.

NRC. 2001. Nutrient Requirements of Dairy Cattle. 7th rev. ed. Natl. Acad. Sci., Washington, DC.

O'Mara, F. P., J. J. Murphy, and M. Rath. 1997. The amino acid composition of protein feedstuffs before and after ruminal incubation and after subsequent passage through the intestines of dairy cows. J. Anim. Sci. 75:1941-1949.

Ørskov, E. R., and I. McDonald. 1979. The estimation of protein degradability in the rumen from incubation measurements weighted according to rate of passage. J. Agric. Sci. 92:499-503.

Pahm, A. A., C. S. Scherer, J. E. Pettigrew, D. H. Baker, C. M. Parsons, and H. H. Stein. 2009. Standardized amino acid digestibility in cecectomized roosters and lysine bioavailability in chicks fed distillers dried grains with solubles. Poult. Sci. 88:571-578.

Prestløkken, E., and O. Rise. 2003. Protein and amino acid digestibility in dairy cows measured with mobile nylon bags recovered in ileum or in faeces. Acta Agric. Scand. Sect. A Anim. Sci. 53:11-20.

Robertson, J. B., and P. J. Van Soest. 1981. The detergent system of analysis and its application to human foods. Pages 123-158 in The Analysis of Dietary Fiber in Food. W. P. T. James and O. Theander, ed. Marcel Dekker Inc., New York, NY. 
Rulquin, H., R. Vérité, J. Guinard-Flament, and P. M. Pisulewski. 2001. Acides amines digestibles dans l'intestin. Origines des variations chez les ruminants et répercussions sur les protéines du lait. INRA Prod. Anim. 14:201-210.

SAS Institute. 2001. SAS User's Guide. Statistics. Version 9.01. SAS Institute Inc., Cary, NC.

Schwab, C. G. 1995. Protected proteins and amino acids for ruminants. Pages 115-141 in Biotechnology in Animal Feeds and Animal Feeding. R. J. Wallace and A. Chesson, ed. VCH Press, Weinheim, Germany.

Sniffen, C. J., J. D. O'Connor, P. J. Van Soest, D. G. Fox, and J. B. Russell. 1992. A net carbohydrate and protein system for evaluating cattle diets. II. Carbohydrate and protein availability. J. Anim. Sci. 70:3562-3577.

Tamminga, S. 1979. Protein degradation in the forestomachs of ruminants. J. Anim. Sci. 49:1615-1630.

Van Soest, P. J., J. B. Robertson, and B. A. Lewis. 1991. Methods for dietary fiber, neutral detergent fiber, and nonstarch polysaccharides in relation to animal nutrition. J. Dairy Sci. 74:3583-3597.

van Straalen, W. M., J. J. Odiga, and W. Mostert. 1997. Digestion of feed amino acids in the rumen and small intestine of dairy cows measured with nylon-bag techniques. Br. J. Nutr. 77:83-97. 